\title{
Pengendalian Trichodina sp. pada Benih Ikan Nila (Oreochromis niloticus) Menggunakan Ekstrak Daun Sirih (Piper betle L.)
}

\author{
Control of Trichodina sp. on Fingerling of Nile Tilapia (Oerochromis \\ niloticus) using Betel Leaf (Piper betle L.) Extract
}

\author{
Dewi Fitrya Nugraheny ${ }^{1}$, Anandita Ekasanti ${ }^{2}$, Emyliana Listiowati ${ }^{3}$, Agung \\ Cahyo Setyawan ${ }^{4}$, Hamdan Syakuri ${ }^{5 *}$ \\ Program Studi Akuakultur, Fakultas Perikanan dan Ilmu Kelautan, \\ Universitas Jenderal Soedirman \\ J1. Dr Soeparno, Komplek GOR Soesilo Soedarman, Karangwangkal, Purwokerto Utara, \\ Kabupaten Banyumas, Jawa Tengah 53122 \\ *corr-author: hamdan.syakuri@unsoed.ac.id
}

\begin{abstract}
ABSTRAK
Ekstrak daun sirih (Piper betle L.) mempunyai potensi untuk digunakan dalam pengendalian Trichodina sp. yang umum ditemukan menginfeksi ikan, termasuk pada benih ikan nila (Oreochromis niloticus). Penelitian ini bertujuan untuk mengetahui konsentrasi dan durasi rendaman ekstrak daun sirih (EDS) yang tidak menyebabkan kematian benih ikan nila, dan mengetahui pengaruh EDS terhadap prevalensi, intensitas, dan kelimpahan Trichodina sp. Daun sirih dikeringkan, dibuat bubuk, dan diekstrak menggunakan air mendidih. Sampel benih ikan nila yang terinfeksi Trichodina sp. dibagi menjadi empat kelompok yang masing-masing terdiri atas 15 ekor. Berdasarkan uji mortalitas benih ikan, rendaman ekstrak daun sirih dilakukan pada konsentrasi 0 (kontrol), 50, 100, dan $200 \mathrm{mg} / \mathrm{L}$ selama dua jam pada empat kelompok ikan tersebut. Setelah perendaman, sebanyak 10 ekor benih per kelompok dimatikan untuk pengamatan parasit secara mikroskopik. Lima ekor dari tiap kelompok dipelihara selama 7 hari untuk pengamatan mortalitas ikan. Hasil menunjukkan bahwa semua konsentrasi ekstrak daun sirih tidak menyebabkan kematian pada sampel ikan setelah perendaman selama 2 jam. Perendaman dengan ekstrak daun sirih dalam penelitian ini tidak menurunkan prevalensi Trichodina sp. Namun demikian, rendaman ekstrak ini pada konsentrasi $100 \mathrm{mg} / \mathrm{L}$ dan $200 \mathrm{mg} / \mathrm{L}$ mampu secara nyata menurunkan intensitas dan kelimpahan parasit ini pada permukaan tubuh (kulit). Setelah 7 hari pemeliharaan kematian benih tidak terjadi pada kelompok konsentrasi rendaman $200 \mathrm{mg} / \mathrm{L}$. Hasil penelitian ini dapat digunakan sebagai dasar untuk menentukan konsentrasi dan durasi rendaman untuk mengendalikan parasit pada ikan secara aman dengan ekstrak daun sirih.
\end{abstract}

Kata kunci: Trichodina sp., daun sirih, Oreochromis niloticus, ekstrak air, pengendalian parasit

\section{ABSTRACT}

Betel leaf (Piper betle L.) extract has the potential to be used in the control of Trichodina sp. which is commonly found to infect fish, including the seeds of tilapia (Oreochromis niloticus). This study aimed to determine the concentration and immersion duration of betel leaf extract (EDS) which does not cause mortality of tilapia seeds, and to determine 
the effect of EDS on the prevalence, intensity, and abundance of Trichodina sp. The betel leaves were dried, powdered, and extracted using boiled water. Tilapia seed samples infected by Trichodina sp. were divided into four groups, each consisting of 15 individuals. Based on the fish seed mortality test, betel leaf extract immersion was carried out at concentrations of 0 (control), 50, 100, and $200 \mathrm{mg} / \mathrm{L}$ for two hours in the four groups of fish. After treatment, 10 fish per group were killed for microscopical parasite observation. Five fish from each group were kept for 7 days to observe fish mortality. The results showed that all concentrations of betel leaf extract did not cause death in fish samples after immersion for 2 hours. Soaking with betel leaf extract in this study did not reduce the prevalence of Trichodina sp. However, soaking this extract at concentrations of $100 \mathrm{mg} / \mathrm{L}$ and $200 \mathrm{mg} / \mathrm{L}$ was able to significantly reduce the intensity and abundance of these parasites on the body surface (skin). After 7 days of maintenance, seed mortality did not occur in the $200 \mathrm{mg} / \mathrm{L}$ immersion group. The results of this study could be used as a basis for determining the concentration and duration of immersion to control parasites in fish safely with betel leaf extract.

Keywords: Trichodina sp., betel leaf extract, Oreochromis niloticus, aqueous extract, parasite control

\section{PENDAHULUAN}

Ikan nila (Oreochromis niloticus) adalah salah satu komoditas unggulan perikanan budidaya air tawar di dunia, termasuk di Indonesia (Boyd, 2004). Jenis ikan ini banyak dibudidayakan hampir di seluruh provinsi dan menjadi salah satu sumber penyediaan protein hewani bagi masyarakat. Konsumsi ikan nila mengalami peningkatan yang signifikan dari tahun ke tahun yang diimbangi dengan produksi yang juga makin meningkat. Sebagai contoh, produksi ikan nila pada tahun 2009 adalah sekitar 323.389 ton dan meningkat menjadi 464.191 ton pada tahun 2010. Peningkatan produksi ikan nila dari tahun 2009-2013 sekitar 54,8\% (Perikanan Budidaya, 2014). Tahun 2017, produksi komoditas ini mencapai lebih dari 1,2 juta ton (Badan Pusat Statistik, 2019). Data tersebut menunjukkan peningkatan produksi ikan nila yang konsisten dari tahun ke tahun. Namun demikian, budidaya ikan nila selalu menghadapi tantangan akibat infeksi pathogen, salah satunya adalah Trichodina sp.

Trichodina sp. adalah ektoparasit yang umum menginfeksi ikan dan menyebabkan penyakit yang dikenal dengan nama Trichodiniasis. Infeksi Trichodina dapat ditemukan baik pada ikan air tawar, payau, maupun laut (Asmat 2001a; Asmat 2001b; Dobberstein \& Palm 2000; Basson \& Van-As 2002; Basson \& Van-As 2006; Cengizler et al., 2001; Bakke \& Harris 1998; Pramono \& Syakuri, 2008; Prasetya et al. 2013; Rustikawati et al., 2004; Wiyatno et al. 2012). Selain menginfeksi ikan, parasit ini juga telah ditemukan pada hewan akuatik lain seperti kerang (Carballal et al., 2001) dan teripang (Boussaid et al. 1999). Pada ikan nila, parasit ini dilaporkan menjadi bagian dari beberapa jenis parasit yang dengan tingkat prevalensi yang tinggi, yaitu sekitar $80 \%$ (Ghiraldelli et al., 2006). Trichodina spp. banyak ditemukan baik di permukaan kulit maupun di insang dan mampu menginfeksi ikan nila di semua musim (Jeronimo et al., 2011). Pengendalian perlu dilakukan karena pada tingkat infeksi tinggi, Trichodina dapat menyebabkan penyakit yang merugikan usaha budidaya ikan (Durborow 2003).

Bahan herbal menjadi alternatif anti parasit untuk mengendalikan Trichodina pada ikan, untuk mengurangi penggunaan bahan kimia sintetis berbahaya. Keuntungan penggunaan bahan alami antara lain adalah aman, mudah diperoleh, murah, tidak meninggalkan residu, dan relatif tidak berbahaya terhadap lingkungan sekitarnya. Salah 
satu bahan alami yang telah terbukti dapat mengobati Trichodiniasis adalah daun pacipaci, yang diujikan pada lele dumbo (Setiadi, 2008). Salah satu kandungan kimia yang terkandung dalam daun paci-paci adalah minyak atsiri, yang terdiri dari fenol dan senyawa turunannya. Tumbuhan lain yang memiliki kandungan minyak atsiri adalah daun sirih (Piper betle L.). Minyak atsiri yang terkandung dalam daun sirih mengandung kavikol yang merupakan antiseptik yang diduga mampu menghambat pertumbuhan parasit (Herawati, 2009; Pradhan et al., 2013; Rekha et al., 2014).

Beberapa penelitian mengenai penggunaan daun sirih dalam pengendalian penyakit ikan telah dilakukan. Ekstrak daun sirih dilaporkan dapat digunakan untuk menanggulangi bakteri patogen pada ikan (Mulia \& Husin, 2012; Lukistyowati \& Syawal, 2013; Bond \& Senggagau, 2019). Selain itu, ekstrak daun sirih dapat digunakan sebagai alternatif obat alami untuk ikan hias tetra yang terinfeksi ektoparasit Ichtyopthiris multifilis, Epysthilis, Dactylogyrus, dan Gyrodactylus (Herawati, 2009). Beberapa penelitian lain tentang penggunaan ekstrak daun sirih untuk mengendalikan parasit termasuk Trichodina sp. pada ikan juga telah dilakukan (Rakhim \& Muharam, 2016; Juliana, 2017; Agustina et al., 2018; Hardhini et al., 2018). Hasil penelitian tersebut menunjukkan potensi ekstrak daun sirih untuk mengendalikan parasit pada ikan. Untuk melengkapi pengetahuan tersebut, penelitian ini dilakukan untuk: 1) mengetahui konsentrasi dan durasi perendaman ekstrak daun sirih untuk mengendalikan Trichodina sp. pada ikan nila (Oreochromis niloticus) dan 2) mengetahui pengaruh rendaman dengan ekstrak daun sirih terhadap prevalensi, intensitas, dan kelimpahan Trichodina sp. pada benih ikan nila.

\section{METODE}

\section{Sampel Ikan dan Pengamatan Pendahuluan}

Sampel benih ikan nila dari pasar benih ikan di Desa Beji, Kabupaten Banyumas berjumlah 20 ekor diamati untuk mengetahui keberadaan ektoparasit Trichodina sp. Pengamatan parasit dilakukan menggunakan mikroskop pada perbesaran 100x. Ikan dimatikan dan sampel mukus diambil dari bagian permukaan tubuh kanan dan bagian insang sejumlah 4 lamella insang kanan. Sampel mukus kemudian diletakkan pada kaca preparat, dihomogenkan dengan larutan fisiologis $(\mathrm{NaCl} 0,9 \%)$, dan ditutup dengan kaca penutup. Setelah pengamatan dengan mikroskop, maka data digunakan untuk mengetahui prevalensi, intensitas, dan kelimpahan Trichodina sp.

Sampel ikan nila diambil dari tempat yang sama untuk tahap penelitian selanjutnya. Sampel ikan terdiri atas dua kelompok ukuran keperluan berbeda: ukuran 2-3 $\mathrm{cm}$ sebanyak 40 individu untuk penentuan konsentrasi dan durasi rendaman ekstrak daun sirih, dan ukuran 4-6 cm sebanyak 80 individu untuk pengujian pengendalian parasit. Ikan dibawa dengan transportasi basah ke laboratorium Fakultas Perikanan dan Ilmu Kelautan Universitas Jenderal Soedirman. Setiap kelompok ikan ditempatkan pada bak plastik berisi air sebanyak 60 liter yang dilengkapi aerator untuk aklimatisasi selama 3 hari. Penelitian dilaksanakan pada Mei-Juni 2014.

\section{Pembuatan ekstrak daun sirih}

Ekstrak daun sirih dilakukan dengan mengikuti penelitan sebelumnya (Setiadi, 2008). Daun sirih segar dicuci dengan air bersih lalu dikeringkan di bawah sinar matahari hingga kering dengan tanda daun mudah dipatahkan. Setelah kering, kemudian daun dihaluskan dengan blender, setelah itu diayak dengan saringan sampai didapatkan bubuk yang halus. Bubuk daun sirih halus disimpan dalam wadah tertutup pada suhu kamar dan tidak terkena sinar matahari langsung. 
Proses ekstraksi dilakukan dengan mencampurkan $8 \mathrm{~g}$ bubuk daun sirih dengan akuades $80 \mathrm{~mL}$. Campuran antara bubuk daun sirih dengan akuades dipanaskan pada suhu $90^{\circ} \mathrm{C}$ selama 30 menit dalam penangas air (Setiadi, 2008). Kemudian hasil seduhan disaring dengan kertas Whatman No.42 untuk menghilangkan suspensi tidak terlarut. Akuades steril ditambahkan untuk mengganti air yang menguap selama proses ekstrak sehingga diperoleh konsentrasi $100 \mathrm{~g} / \mathrm{L}$ sebagai larutan stok dengan volume $80 \mathrm{~mL}$.

\section{Penentuan Konsentrasi dan Durasi Rendaman Ekstrak Daun Sirih}

Larutan stok ekstrak daun sirih diencerkan menggunakan air bersih sehinga diperoleh konsentrasi: $0 \mathrm{mg} / \mathrm{L}, 0,3 \mathrm{mg} / \mathrm{L}, 3 \mathrm{mg} / \mathrm{L}, 30 \mathrm{mg} / \mathrm{L}, 50 \mathrm{mg} / \mathrm{L}, 100 \mathrm{mg} / \mathrm{L}, 200$ $\mathrm{mg} / \mathrm{L}, 300 \mathrm{mg} / \mathrm{L}, 3 \mathrm{~g} / \mathrm{L}, 4,5 \mathrm{~g} / \mathrm{L}, 6 \mathrm{~g} / \mathrm{L}$, dan $12 \mathrm{~g} / \mathrm{L}$. Setiap konsentrasi digunakan untuk perendaman sampel ikan nila selama 12 jam (720 menit). Waktu perendaman 12 jam mengacu pada penelitian Herawati (2009). Perendaman dilakukan menggunakan wadah yang berisi 2 liter air. Kondisi ikan diamati secara periodik selama perendaman. Waktu kematian ikan (menit) dicatat untuk menentukan konsentrasi dan durasi yang aman untuk diterapkan dalam pengendalian Trichodina sp., yaitu $0 ; 50 \mathrm{mg} / \mathrm{L} ; 100 \mathrm{mg} / \mathrm{L}$; dan 200 $\mathrm{mg} / \mathrm{L}$ selama $2 \mathrm{jam}$.

\section{Rendaman Ektrak Daun Sirih untuk Mengendalikan Trichodina sp.}

Sampel ikan dikelompokkan menjadi 4 kelompok yang masing-masing terdiri atas 15 individu. Setiap kelompok kemudian diberi satu perlakuan dari empat perlakuan, yaitu rendaman tanpa ekstrak daun sirih (Kontrol, $0 \mathrm{mg} / \mathrm{L}$ ), dengan ektrak daun sirih pada konsentrasi $50 \mathrm{mg} / \mathrm{L}, 100 \mathrm{mg} / \mathrm{L}$, dan $200 \mathrm{mg} / \mathrm{L}$. Perendaman dilakukan selama dua jam pada wadah berisi 2 liter air. Pengukuran $\mathrm{pH}$ dan temperatur air dilakukan sebelum dan setelah air pemeliharaan diberi ekstrak daun sirih.

Setelah perendaman, 10 ekor benih ikan nila dari setiap perlakuan dimatikan dan sampel mukus diambil dari bagian permukaan tubuh kanan dan bagian insang kanan. Mukus diletakkan pada gelas objek, dihomogenkan dengan larutan fisiologis $(\mathrm{NaCl}$ 0,9\%), dan dikeringanginkan pada suhu ruang untuk pewarnaan perak nitrat (Foissner, 1991). Preparat mukus ditetesi perak nitrat 1\%, dan didiamkan selama 15 menit. Setelah itu, preparat dicuci dengan air mengalir dan kemudian dijemur di bawah sinar matahari dalam kondisi terendam air dengan kedalaman $3 \mathrm{~cm}$. Preparat diamati dengan mikroskop dengan perbesaran 100X untuk mengetahui keberadaan Trichodina sp. Hasil pengamatan kemudian digunakan untuk menghitung prevalensi, intensitas, dan kelimpahan parasit dengan rumus:

$$
\begin{aligned}
& \text { Prevalensi (\%) }=\frac{\sum \text { Ikan yang terinfeksi }}{\sum \text { Ikan yang diperiksa }} \times 100 \% \\
& \text { Intensitas (ind/ikan) }=\frac{\sum \text { Trichodina }}{\sum \text { Ikan yang terinfeksi }} \\
& \text { Kelimpahan (ind/ikan) }=\frac{\sum \text { Trichodina }}{\sum \text { Ikan yang diperiksa }}
\end{aligned}
$$


Air yang telah digunakan untuk perendaman disaring dengan planktonet (no. 25). Hasil penyaringan dimasukkan dalam botol, diberi 3 tetes formalin 4\%, dan disimpan pada suhu ruang sampai tahap berikutnya. Keberadaan Trichodina sp. diamati menggunakan mikroskop pada perbesaran 100X untuk membuktikan adanya parasit yang terlepas dari ikan akibat perendaman dengan ekstrak daun sirih.

\section{Analisis Data}

Data prevalensi Trichodina sp. dan kelangsungan hidup benih ikan dianalisis secara deskriptif. Data intensitas dan kelimpahan Trichodina sp. dianalisis varian atau analysis of variance (Anova, $\mathrm{p} \leq 0,05$ ). Uji beda nyata terkecil/least significant difference (BNT/LSD) dilakukan pada $\mathrm{p} \leq 0,05$ jika hasil Anova menunjukkan perbedaan nyata.

\section{HASIL DAN PEMBAHASAN}

\section{Tingkat infeksi Trichodina sp. pada sampel benih ikan nila (Oreochromis niloticus)}

Sampel benih ikan nila yang digunakan dalam penelitian ini terinfeksi Trichodina sp. dengan tingkat infeksi yang tinggi (Error! Reference source not found.). Parasit ini ditemukan pada permukaan tubuh di semua sampel ikan (prevalensi 100\%) dan pada insang di 95\% sampel ikan. Intensitas Trichodina sp. pada benih ikan nila juga relatif tinggi, yaitu sekitar 17 parasit/ikan terinfeksi pada insang, dan sekitar 57 parasit/ikan terinfeksi pada permukaan tubuh. Nilai kelimpahan parasit ini relatif sama dengan nilai intensitas. Hal ini menunjukkan bahwa sampel ikan sangat tepat digunakan untuk menguji pengaruh rendaman ekstrak daun sirih terhadap infeksi Trichodina sp.

\section{Durasi dan konsentrasi aman ekstrak daun sirih (Piper betle L.) untuk benih ikan nila (Oreochromis niloticus)}

Penentuan konsentrasi dan durasi dilakukan berdasarkan waktu kematian benih ikan nila berukuran 2-3 cm setelah direndam dengan ekstrak daun sirih selama 12 jam (720 menit) pada beberapa konsentrasi (Gambar 2). Hasil menunjukkan bahwa rendaman ektrak daun sirih pada konsentrasi $\leq 100 \mathrm{mg} / \mathrm{L}$ tidak menyebabkan kematian pada benih ikan nila. Kematian ikan yang direndam pada konsentrasi $200 \mathrm{mg} / \mathrm{L}$ terjadi pada sekitar menit ke-190. Hal ini menunjukkan bahwa konsentrasi $\leq 200 \mathrm{mg} / \mathrm{L}$ aman digunakan pada benih ikan nila dengan durasi rendaman selama sekitar 2 jam. Waktu kematian ikan semakin cepat seiring dengan peningkatan konsentrasi ekstrak daun sirih. Kematian ikan terjadi pada menit ke-3 setelah direndam ekstrak daun sirih pada konsentrasi $12 \mathrm{~g} / \mathrm{L}$. Hasil ini sesuai dengan Herawati (2009), yang menyatakan bahwa pengaruh ekstrak daun sirih dengan konsentrasi yang tinggi akan membahayakan kehidupan ikan meskipun dapat menghambat perkembangbiakkan ektoparasit. 


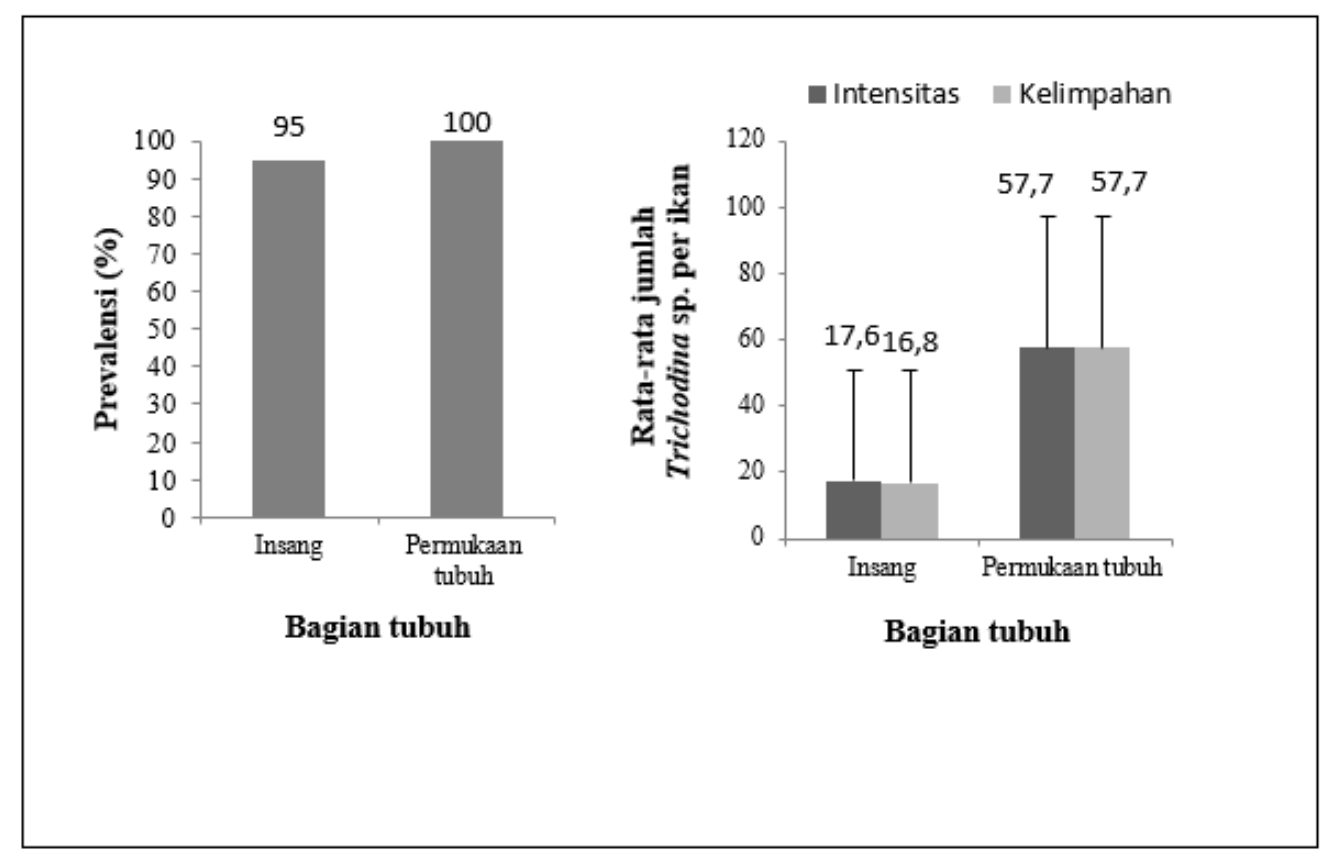

Gambar 1. Infeksi Trichodina sp. pada benih ikan nila (Oreochromis niloticus) sebelum perlakuan : A) Prevalensi B) Intensitas dan kelimpahan

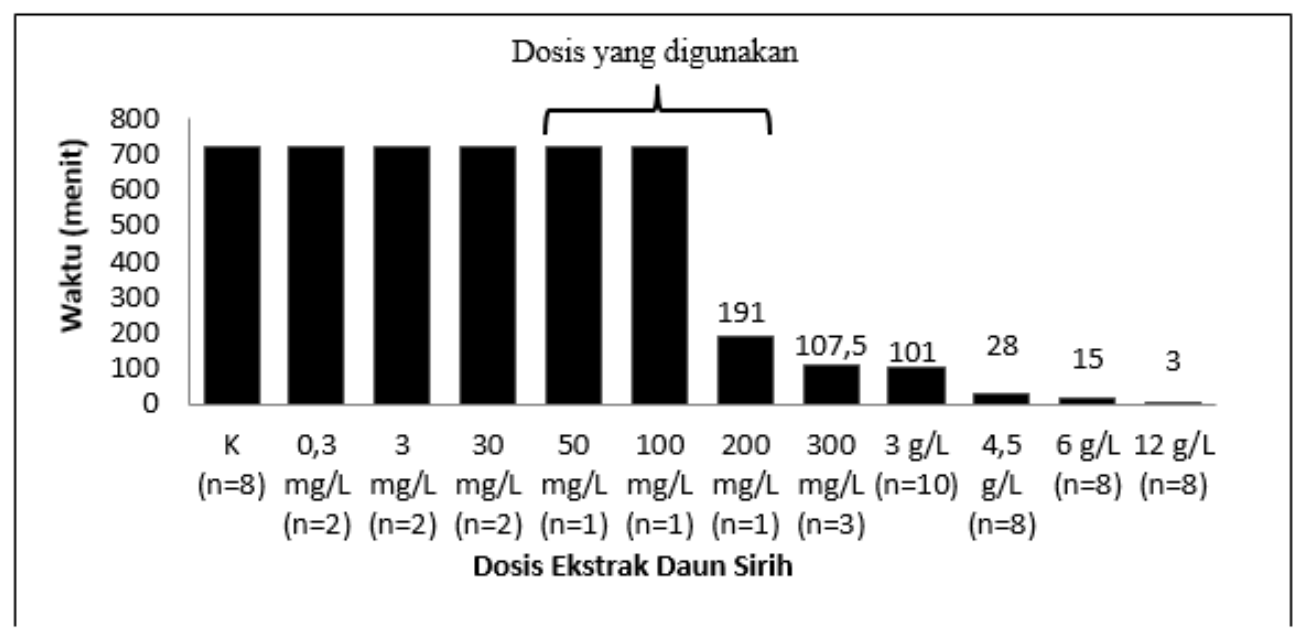

Gambar 2. Waktu kematian benih ikan nila (Oreochromis niloticus) terhadap beberapa dosis ekstrak daun sirih. Pengamatan selama jangka waktu 12 jam ( $n=$ jumlah awal benih)

\section{Pengaruh ekstrak daun sirih terhadap Trichodina $\mathbf{s p .}$}

Hasil penelitian ini menunjukkan bahwa ekstrak daun sirih mampu menurunkan prevalensi Trichodina sp. pada insang benih ikan nila. Gambar 3 menunjukkan prevalensi Trichodina sp. benih ikan nila setelah direndam dengan ekstrak daun sirih selama dua jam. Prevalensi Trichodina sp. pada insang ikan yang direndam dengan konsentrasi 200 $\mathrm{mg} / \mathrm{L}$ adalah $60 \%$, lebih rendah dibandingkan konsentrasi $100 \mathrm{mg} / \mathrm{L}(80 \%), 50 \mathrm{mg} / \mathrm{L}$ (100\%), dan kontrol (90\%). Hal ini juga mengindikasikan bahwa konsentrasi $50 \mathrm{mg} / \mathrm{L}$ tidak cukup kuat untuk menurunkan prevalensi parasit ini pada insang benih ikan nila. Hanya saja, penurunan prevalensi parasit tidak pada permukaan tubuh (kulit) benih ikan 
nila. Prevalensi Trichodina sp. di permukaan tubuh tidak mengalami penurunan yaitu 100\% (Gambar 3). Hal ini dapat disebabkan jumlah Trichodina sp. pada permukaan tubuh lebih banyak dibandingkan dengan jumlah parasit pada insang.

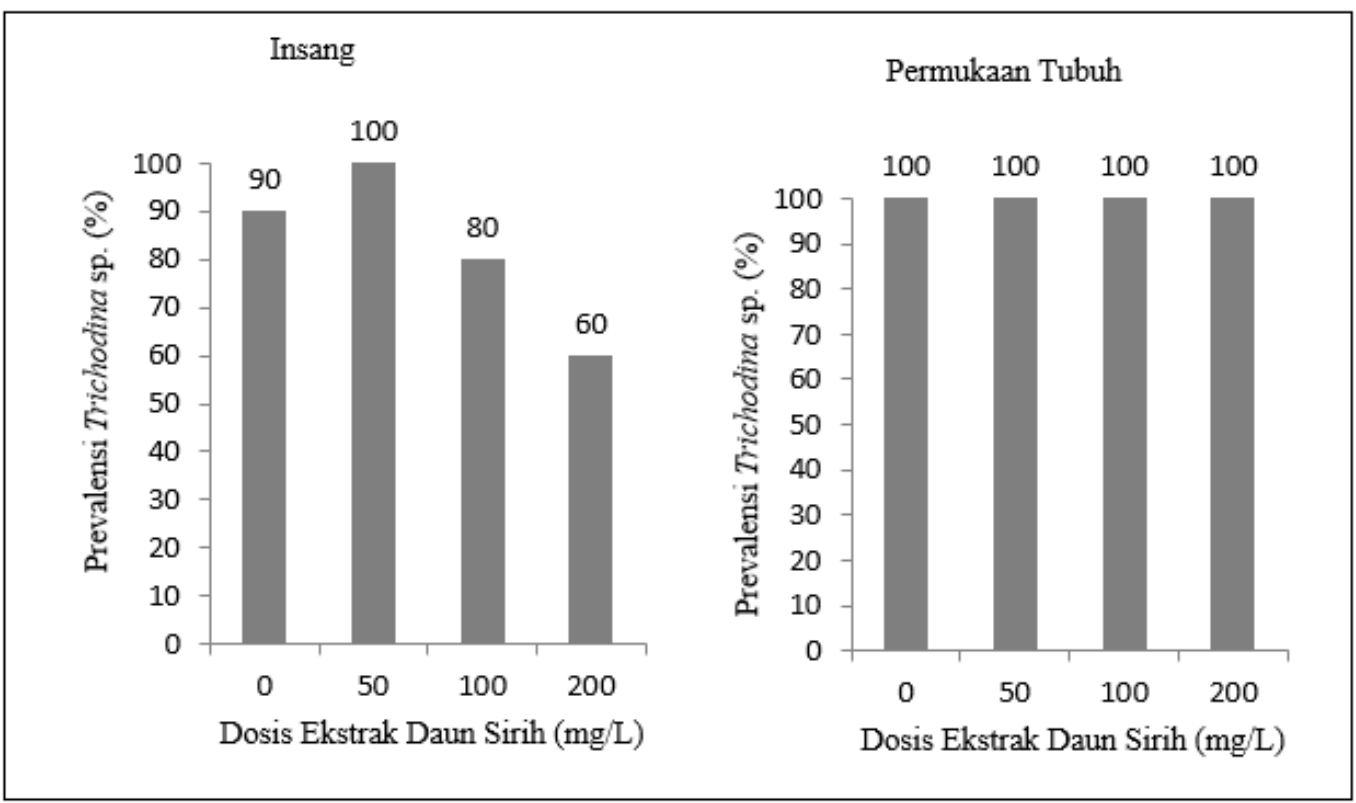

Gambar 3. Prevalensi Trichodina sp. pada benih ikan nila (Oreochromis niloticus) setelah perendaman dengan ekstrak daun sirih selama 2 jam : A) Insang, B)

Permukaan tubuh

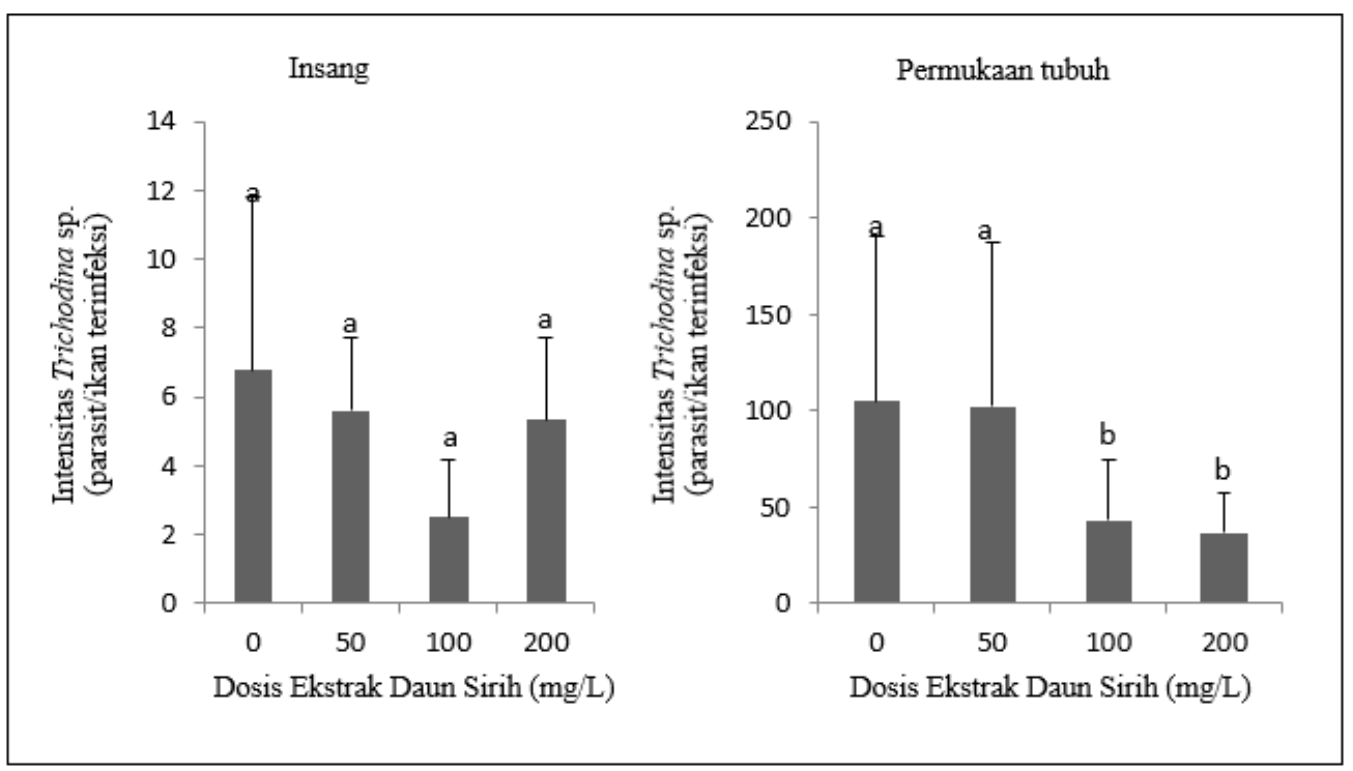

Gambar 4. Intensitas Trichodina sp. setelah perendaman ekstrak daun sirih selama 2 jam pada benih ikan nila (Oreochromis niloticus): A) Insang, B) Permukaan tubuh. Huruf yang sama pada kolom menunjukkan tidak terdapat perbedaan yang nyata antar rata-rata $(\mathbf{p} \leq 0,05)$ 
Perendaman menggunakan ekstrak daun sirih dalam penelitian ini mampu menurunkan intensitas dan kelimpahan Trichodina sp. pada benih ikan nila, khususnya di permukaan tubuh. Intensitas dan kelimpahan Trichodina sp. di permukaan tubuh benih ikan nila yang direndam dengan ekstrak daun sirih pada konsentrasi $100 \mathrm{mg} / \mathrm{L}$ dan 200 $\mathrm{mg} / \mathrm{L}$ secara nyata lebih rendah dibandingkan pada konsentrasi $50 \mathrm{mg} / \mathrm{L}$ dan kontrol (Gambar 4 dan Gambar 5). Perendaman dengan ekstrak daun sirih juga cenderung menurunkan jumlah Trichodina sp. pada insang benih ikan nila, meskipun nilai intensitas dan kelimpahan parasit ini tidak berbeda nyata antar perlakuan. Hasil ini menunjukkan bahwa ekstrak daun sirih lebih efekfif menurunkan jumlah Trichodina sp. pada permukaan tubuh dibandingkan pada insang ikan nila. Hasil penelitian lain menunjukkan hal yang sama, dimana perendaman ekstrak daun sirih dapat menurunkan intensitas ektoparasit pada ikan hias neon tetra (Herawati, 2009).

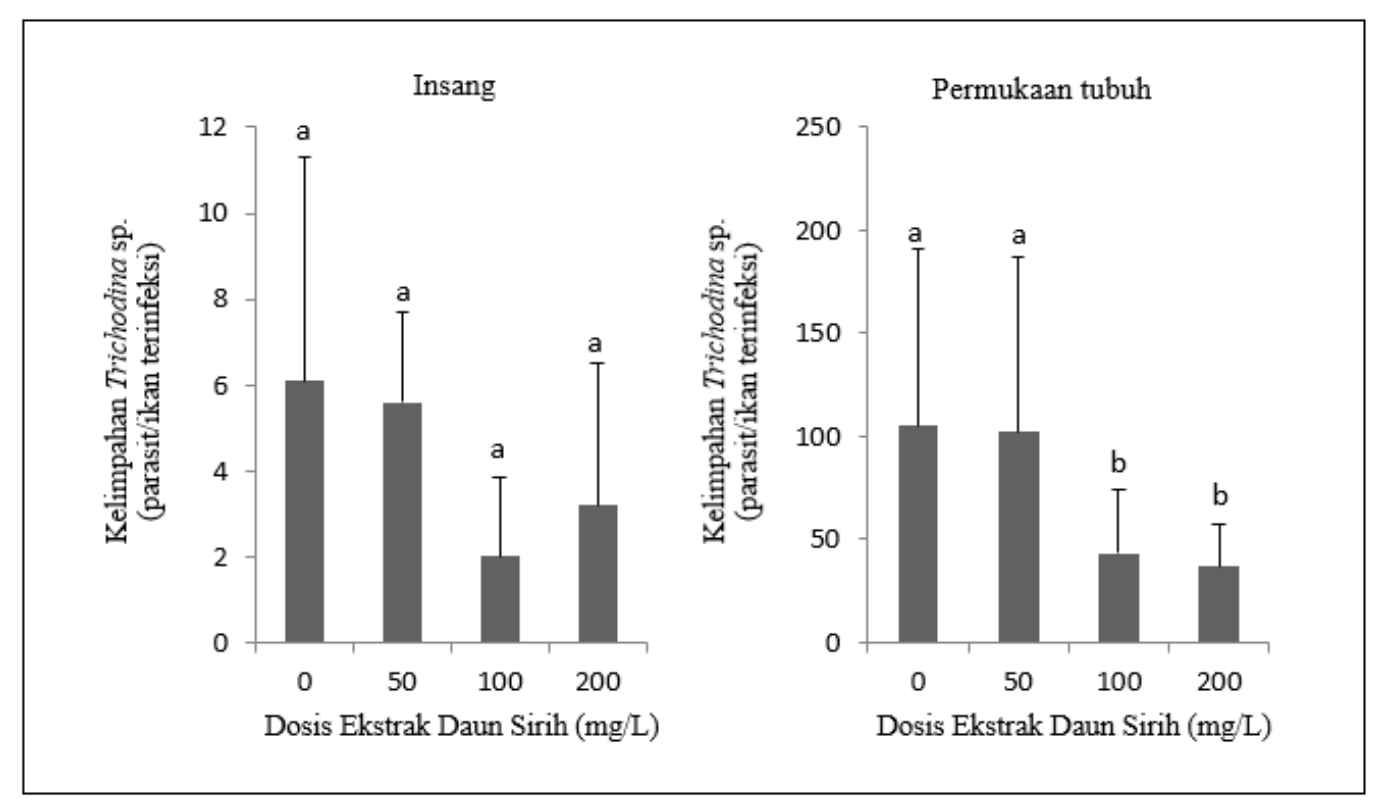

Gambar 5. Kelimpahan Trichodina sp. setelah perendaman ekstrak daun sirih selama 2 jam pada benih ikan nila (Oreochromis niloticus) : A) Insang, B)

Permukaan tubuh (huruf yang sama pada kolom menunjukkan tidak terdapat perbedaan yang nyata pada $p<0,05$ )

Penurunan intensitas dan kelimpahan Trichodina sp. pada benih ikan nila setelah perendaman menggunakan ekstrak daun sirih mengindikasikan bahwa sejumlah parasit terlepas dari tubuh ikan. Dalam penelitian ini, air yang telah digunakan untuk perlakuan disaring menggunakan planktonet untuk pengamatan parasit. Trichodina sp. yang tertangkap planktonet dapat dilihat pada Gambar 6. Hal ini membuktikan bahwa perendaman dengan esktrak daun sirih menyebabkan Trichodina sp. mati dan terlepas dari tubuh ikan. 


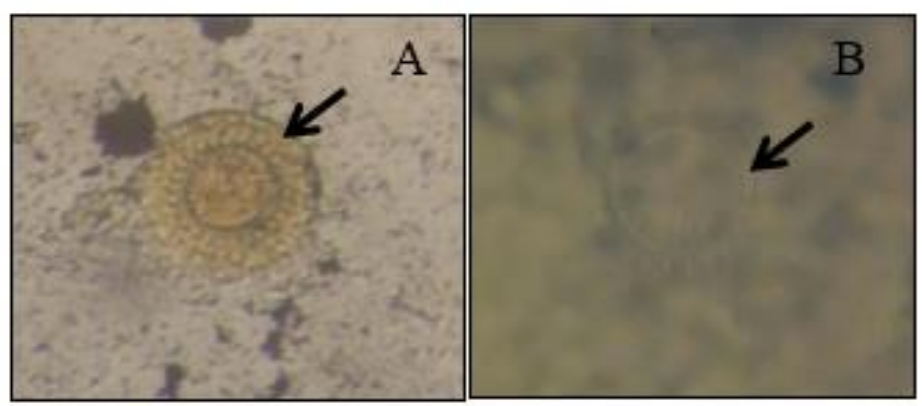

Gambar 6. Trichodina sp. yang menginfeksi benih ikan nila (Oreochromis niloticus) yang diperoleh dari : A. Permukaan tubuh ikan (pewarnaan perak nitrat 2\%) dan,

B. Hasil penyaringan air menggunakan planktonet dari perlakuan $200 \mathrm{mg} / \mathrm{L}$

Perendaman dengan ekstrak daun sirih dengan konsentrasi dan durasi yang digunakan dalam penelitian ini tidak menyebabkan kematian benih ikan nila. Gambar 7 menunjukkan kelompok ikan pada semua perlakuan memiliki kelulushidupan sebesar $100 \%$ setelah perendaman dengan ekstrak daun sirih selama 2 jam. Empat konsentrasi perlakuan yang digunakan telah terbukti aman bagi benih ikan nila. Hal ini sesuai dengan hasil uji toksisitas sebelumnya. Oleh karena itu, uji toksisitas perlu dilakukan sebelum menentukan konsentrasi yang tepat bagi penelitian utama agar keberhasilan dalam penelitian utama dapat dicapai. Hasil penelitian ini sesuai dengan penelitian sebelumnya yang membuktikan daun sirih sebagai obat alternatif yang aman bagi ikan neon tetra (Herawati, 2009).

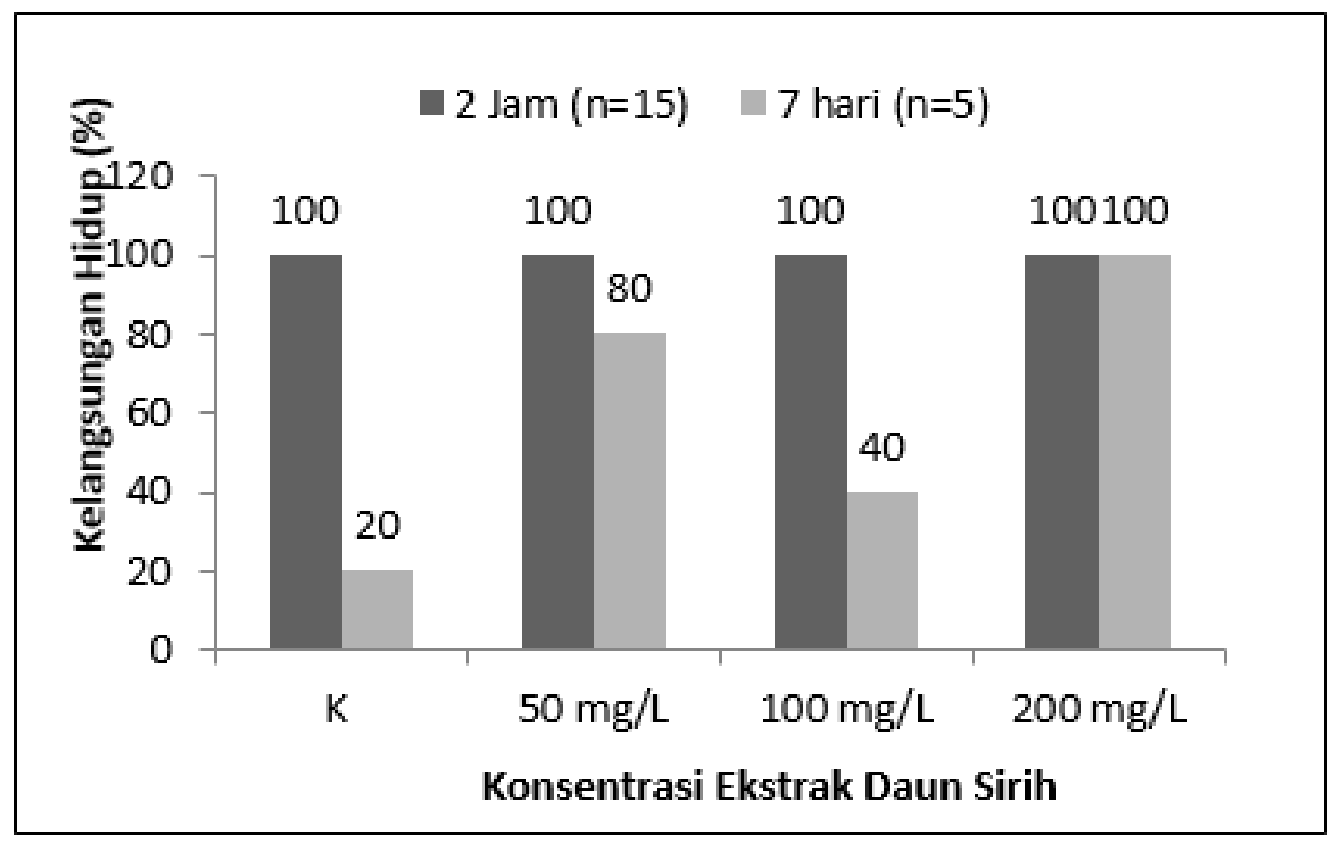

Gambar 7. Kelangsungan hidup benih ikan nila (Oreochromis niloticus) setelah 2 jam perendaman dengan ekstrak daun sirih dan 7 hari setelah perlakuan

Setelah ikan dipelihara selama 7 hari paska perlakuan, kematian terjadi pada kelompok kontrol, konsentrasi $50 \mathrm{mg} / \mathrm{L}$, dan konsentrasi $100 \mathrm{mg} / \mathrm{L}$ (Gambar 7). Hal yang menarik adalah kematian tidak terjadi pada kelompok ikan yang diberi konsentrasi 
ekstrak daun sirih tertinggi $(200 \mathrm{mg} / \mathrm{L})$. Hal ini mengindikasikan kematian ikan pada perlakuan $50 \mathrm{mg} / \mathrm{L}$ dan $100 \mathrm{mg} / \mathrm{L}$ tidak terjadi karena ekstrak daun sirih. Kelulushidupan ikan kontrol justru paling rendah (20\%) jika dibandingkan ikan perlakuan $50 \mathrm{mg} / \mathrm{L}$ dan $100 \mathrm{mg} / \mathrm{L}$ (80\% dan 40\%), yang menunjukkan adanya faktor lain yang menyebabkan kematian ikan. Faktor tersebut tidak dapat diketahui dengan pasti dalam penelitian ini. Hanya saja, fenomena ini dapat dikaitkan dengan tingkat infeksi Trichodina sp. Pemeliharaan selama 7 hari menunjukkan bahwa kematian terbanyak pada perlakuan kontrol yang kemungkinan disebabkan tidak dilakukannya pengobatan dengan ekstrak daun sirih. Hal tersebut mengakibatkan Trichodina sp. dapat berkembang biak dan membuat daya tahan tubuh benih menjadi menurun, sedangkan pada perlakuan tertinggi yaitu konsentrasi $200 \mathrm{mg} / \mathrm{L}$ tidak ada benih yang mati. Hal ini karena pengaruh dari ekstrak daun sirih yang dapat menurunkan jumlah Trichodina sp. Seperti pendapat Herawati (2009), kandungan kavikol dalam daun sirih yang terasa pedas dan bersifat anti parasitik.

Penelitian ini dilakukan pada kondisi $\mathrm{pH}$ dan temperatur air yang sesuai untuk pemeliharaan ikan nila. Nilai $\mathrm{pH}$ air sebelum dan setelah penambahan ekstrak daun sirih adalah 7. Temperatur air selama penelitian stabil pada $28^{\circ} \mathrm{C}$. Hasil pengukuran $\mathrm{pH}$ dan temperatur ini sama seperti pada penelitian Hedianto dan Cahyanigsih (2004), dimana tidak ada pengaruh perendaman dengan tanaman Caprofish terhadap perubahan $\mathrm{pH}$ dan temperatur yaitu $\mathrm{pH}$ 6,09 dan temperatur $24^{\circ} \mathrm{C}$ dari awal hingga akhir penelitian. Data kualitas air dalam penelitian ini masih dalam kisaran kelangsungan hidup ikan nila. Kisaran nilai $\mathrm{pH}$ air tempat hidup ikan nila yaitu 6-8,5, namun pertumbuhan optimal terjadi pada pH 7-8 (Panggabean, 2009). Batas suhu untuk kelangsungan hidup ikan nila berkisar antara $11-42^{\circ} \mathrm{C}$ (FAO, 2005).

Uji pengendalian Trichodina sp. pada ikan nila dalam penelitian ini dilakukan menggunakan ekstrak air daun sirih pada kisaran konsentrasi yang luas. Ekstraksi dengan pelarut air akan memudahkan pembudidaya ikan dalam menggunakan bahan ini untuk mengendalikan parasit. Waktu kematian ikan akibat penggunaan ekstrak daun sirih diamati pada konsentrasi berkisar 0,3 mg-6 g/L. Data ini sangat berguna dalam menentukan berbagai kombinasi konsentrasi dan durasi perendaman untuk mengendalikan Trichodina sp. atau pun parasit lain pada ikan. Hal ini yang belum pernah dilaporkan dari beberapa penelitian sebelumnya (Herawati, 2009; Rakhim \& Muharam, 2016; Juliana, 2017; Agustina et al., 2018; Hardhini et al., 2018).

Penelitian ini menunjukkan bahwa penggunaan ekstrak daun sirih dengan konsentrasi yang berbeda mempengaruhi prevalensi di bagian insang atau permukaan tubuh, serta intensitas dan kelimpahan Trichodina sp. pada benih ikan nila di bagian insang atau permukaan tubuh. Penurunan prevalensi Trichodina sp.hanya terjadi di insang, sedangkan prevalensi Trichodina sp. di permukaan tubuh tidak mengalami penurunan karena semua benih ikan nila yang diperiksa masih terdapat Trichodina sp. Penurunan intensitas dan kelimpahan Trichodina sp. terjadi di permukaan tubuh dan insang, namun penurunannya belum dapat membersihkan total Trichodina sp. pada benih ikan nila. Penelitian lebih lanjut perlu dilakukan untuk menemukan konsentrasi dan durasi rendaman dengan ekstrak air daun sirih yang dapat membebaskan Trichodina sp. dari ikan nila. Penggunaan ekstrak air dalam penelitian ini belum dapat memberikan hasil sebaik penggunaan ekstrak ethanol daun sirih yang pada konsentrasi rendaman 0,01 ppm dapat membebaskan ikan dari infeksi Trichodina sp. (Agustina et al. 2018).

Penelitian mengenai ekstrak daun sirih terhadap pengobatan Trichodina sp. telah dilakukan dengan menggunakan tanaman herbal lainnya, selain daun sirih. Hasil penelitian yang dilakukan Herdianto dan Cahyaningsih (2004) menggunakan Caprofish untuk pengendalian populasi Ichtyopthirius multiflis dan Trichodina sp. pada ikan Maanvis (Pterophyllum scalare) menunjukkan adanya penurunan populasi Trichodina sp. 
yang menempel pada tubuh ikan. Hal tersebut sama dengan hasil penelitian ini yang juga menurunkan jumlah Trichodina sp., baik di insang maupun permukaan tubuh. Selain Caprofish, daun paci-paci (Leucas lavandulaefolia) ternyata mampu mengendalikan perkembangan populasi Trichodina sp. pada benih ikan lele dumbo (Clarias sp.) selama perendaman 24 jam dengan penurunan infestasi Trichodina sp. sebesar $84 \%$ dengan konsentrasi 2 g/L (Setiadi, 2008). Hal ini menunjukkan metode pengendalian Trichodina sp. dengan menggunakan daun paci-paci lebih efektif dibandingkan metode pengendalian Trichodina sp. menggunakan daun sirih. Perbedaan efektivitas tersebut juga dapat dikarenakan lama perendaman dari daun paci-paci berbeda jauh dengan penelitian ini yaitu selama 2 jam. Purwanti et al. (2012) membuktikan bahwa perendaman benih ikan kerapu macan dalam ekstrak jahe pada konsentrasi $0,5 \%$ dalam waktu 10 menit berpengaruh terhadap penurunan jumlah ektoparasit protozoa, salah satunya adalah Trichodina sp. Penelitian Chitmanat et al. (2004) membuktikan bahwa ekstrak bawang putih dapat mengobati infeksi Trichodina sp. pada benih ikan nila setelah 2 hari pengobatan dengan 800 ppm bawang putih.

Dibandingkan dengan penelitian Herawati (2009), penelitian ini menggunakan metode ekstraksi daun sirih yang berbeda. Perbedaannya adalah pada penelitian tersebut menggunakan air rebusan dari daun sirih segar, sedangkan pada penelitian ini daun sirih dikeringkan terlebih dahulu kemudian dilakukan ekstraksi. Kelebihan dari proses pengeringan daun sirih adalah memudahkan dalam pengelolaan dan agar lebih tahan disimpan dalam jangka waktu yang lama (Hernani dan Nurdjanah, 2009), sehingga mudah digunakan sewaktu diperlukan.

\section{KESIMPULAN}

Berdasarkan hasil penelitian ini dapat disimpulkan bahwa konsentrasi ekstrak daun sirih yang digunakan dalam perlakuan utama terbukti aman bagi kelangsungan hidup benih ikan nila selama perendaman 2 jam. Ekstrak daun sirih dengan konsentrasi 100 dan $200 \mathrm{mg} / \mathrm{L}$ secara signifikan menurunkan intensitas Trichodina sp. pada permukaan tubuh ikan nila. Perlakuan dalam penelitian ini tidak dapat menurunkan prevalensi parasit ini. Penelitian lebih lanjut perlu dilakukan untuk menentukan konsentrasi dan durasi yang aman untuk membebaskan ikan dari infeksi Trichodina sp. dengan menggunakan ekstrak daun sirih.

\section{UCAPAN TERIMA KASIH}

Terima kasih disampaikan kepada Fakultas Perikanan dan Ilmu Kelautan Universitas Jenderal Soedirman (FPIK UNSOED) atas semua fasilitas yang digunakan dalam penelitian ini. Penelitian ini adalah bagian dari tugas akhir atas nama Dewi Fitrya Nugraheny di FPIK UNSOED.

\section{DAFTAR PUSTAKA}

Agustina, S. S., Mutalib, Y., \& Bakri, A. A. (2018). Uji Daya Antiparasit Konsentrasi Ekstrak Piper Betle L. Terhadap Parasit Trichodina sp. yang Menginfeksi Benih Ikan Nila (Oreochromis Niloticus). In Seminar Nasional Kelautan XIII, Implementasi Hasil Riset Sumber Daya Laut dan Pesisir dalam Rangka Mencapai Kemandirian Ekonomi, Fakultas Teknik dan Ilmu Kelautan Universitas Hang Tuah, Surabaya Nasioanal, (pp. C2-9-C2-16).

Asmat, G.S.M. 2001a. Trichodina canningensis sp.n. (ciliophora : trichodinidae) from an Indian estuarine fish Mystus gulio (Hamilton) (Bagridae). Acta Protozool $40: 147$ 151 
Asmat, G.S.M. 2001b. Trichodina porocephalusi sp.n. (ciliophora : trichodinidae) from an Indian Flathead Sleeper, Ophiocora porochepalus (Valenciennes) (eleotrididae). Acta Protozool $40: 297-301$

Bakke, T.A. and P.D. Harris. 1998. Diseases and parasites in Wild Atlantic Salmon (Salmo salar) population. Can.J.Fish.Aquat.Sci. 55 : 247-266

Basson, L. and J.G. Van-As. 2002. Trichodinid ectoparasites (ciliophora : peritrichia) of freshwater fishes of the family Anabantidae from Okavango River and Delta (Botswana). Folia Parasitologica 49 : 169-181

Basson, L., and Van As, J. 2006. Trichodinidae And Other Ciliophorans (Phylum Ciliophora)dalam Woo, P.T.K. 2006. Fish Diseases And Disorders, Volume 1: Protozoan And Metazoan Infections Second Edition. University of Guelph, Canada.

Bond, M. M., \& Senggagau, B. (2019). Application of piper betel leaf (piper betle linn) extract to control fish pathogenic bacteria in-vitro. IOP Conference Series: Earth and Environmental Science, 383, 12030. https://doi.org/10.1088/1755$1315 / 383 / 1 / 012030$

Boussaid, B., J.L. Grippori, T. Renault, G. Tige, and G. Dorange. 1999. Trichodina sp.infestation of Crassostrea gigas Oyster gills in Brittany, France. J.of Invert. Path. $73: 339-342$

Boyd, E.C. 2004. Farm-Level Issues In Aquaculture Certification: Tilapia. Report Commissioned by WWF-US in 2004. Auburn University, Alabama 36831.

Carballal, M.J., D. Iglesias, J. Santamarina, B. Ferro-Soto and A. Villalba. 2001. Parasites and pathologic conditions of the Cockle Cerastoderma edule of The Coast of Galicia (NW Spain). J.of.Invert.Path. $78:$ 87-97

Cengizler, I., N. Aytac, A. Sahan, A.A. Ozak and E. Gene. 2001. Ecto-endo parasites investigation on Mirror Carp (Cyprinus carpio L., 1758) captured from The River Seyhan Turkey. E.U. Journ. Of Fisheries and Aquatic Sci. 18 : 87-90

Chitmanat, Chanagun., Tongdonmuan, Kitiwan., Nunsong, Wichan. 2004. The Use of Crude Extracts From Traditional Medicinal Plants to Eliminate Trichodina sp. in Tilapia (Oreochromis niloticus) Fingerlings. Short Communication. 359-364.

Durborow, R.M. 2003. Protozoan parasites. SRAC publication No. 471.7 pp

Dobberstein, R.C. and H.W. Palm. 2000. Trichodinid ciliates (Peritrichia : trichodinidae) from the Bay of Kiel, with description of Trichodina claviformis sp.n. Folia Parasitologica 47 : 81-90

FAO. 2005. Cultured Aquatic Species Information Programme. Oroechromis niloticus. Text by Rakocy, J.E. In: FAO Fisheries and Aquaculture Department. Rome. http://www.fao.org//fihery/culturedspecies/Dicentrarchus_labrax/en.Diakses pada tanggal 6 Maret 2014.

Foissner, W. (1991). Basic light and scanning electron microscopic methods for taxonomic studies of ciliated protozoa. European Journal of Protistology, 27(4), 313-330. https://doi.org/10.1016/S0932-4739(11)80248-8

Ghiraldelli, Luciana., Martins, Mauricio Laterca., Yamashita, Marcela Maia., Jeronimo, Gabriela, Tomas. 2006. Ectoparasites Influence on the Haemotological Parameters of Nile Tilapia and Carp Cultured in the State of Santa Catarina, South Brazil. Laboratory of Diagnosis and Pathology in Aquaculture. Departement of Aquaculture. Federal University of Santa Catarina. Brazil. Journal of Fisheries and Aquatic Science, 1 (3) : 270-276. 
Hardhini, R., Amir, S., \& Setyowati, D. N. (2018). Pengaruh Ekstrak Daun Jambu Biji (Psidium guajava), Daun Pepaya (Carica papaya) dan Daun Sirih (Piper betle) Terhadap Ektoparasit pada Ikan Karper (Cyprinus carpio). Jurnal Perikanan, 8(1), 32-39.

Herawati, Vivi Endar. 2009. Pemanfaatan Daun Sirih (Piper betle) Untuk Menanggulangi Ektoparasit Pada Ikan Hias Tetra. PENA Akuatika, 1 (1) : 8-13.

Herdianto, Yanuarso Eddy., Cahyaningsih, Umi. 2004. Caprofish Sebagai Antiprotozoa Herbal Dan Pengaruhnya Terhadap Populasi Ichtyopthirius multifilis Dan Trichodina sp. Pada Ikan Maanvis (Pterophyllum scalare). Prosiding Seminar Nasional XI Persada. 117-124.

Hernani. Nurdjanah, Rahmawati. 2009. Aspek Pengeringan Dalam Mempertahankan Kandungan Metabolit Sekunder Pada Tanaman Obat. Perkembangan Teknologi TRO, 21 (2) : 33-39.

Jeronimo, G.T., Speck, G.M., Cechinel, M.M., Goncalves, E.L.T., Martins, M.L. 2011. Seasonal Variation On The Ectoparasitic Communities Of Nile Tilapia Cultured In Three Regions In Southern Brazil. Sanidade de Organismos Aquaticos. Departement de Aquicultura. CCA. Universidade Federal de Santa Catarina. Brazil. Braz. J. Biol, 71 (2).

Juliana. (2017). Intensitas Ektoparasit Monogenea (Cichlidogyrus sp.) pada Benih Ikan Nila (Oreochromis niloticus) Melalui Pemberian Larutan Daun Sirih (Piper betle Linn) yang Ramah Lingkungan. In Prosiding Seminar Nasional Kemaritiman dan Sumberdaya Pulau-Pulau Kecil (pp. 71-76).

Lukistyowati, I., \& Syawal, H. (2013). Potensi Pakan yang Mengandung Sambiloto (Andrographis paniculata) dan Daun Jambu Biji (Psidium guajava) untuk Menanggulang Bakteri Aeromonas hydrophila pada Ikan Baung (Mystus nemurus). Jurnal Akuakultur Rawa Indonesia, 1(2), 135-147.

Mulia, D. S., \& Husin, A. (2012). Efektivitas Ekstrak Daun Sirih dalam Menanggulangi Ikan Patin yang Terinfeksi Bakteri Aeromonas hydrophila. Sainteks, 9(2), 22-33. https://doi.org/10.30595/sainteks.v9i2.268

Panggabean, A. 2009. Budidaya Ikan Nila (Oreochromis niloticus). Departemen Kehutanan. Fakultas Pertanian. Sumatera Utara.

Perikanan Budidaya, Ditjen. 2014. Perikanan Budidaya Indonesia. http://www.djpb.kkp.go.id.Diakses pada tanggal 21 Maret 2014.

Pradhan, D. Suri, K.A. Pradhan, K.D. Biswasroy, P. 2013. Golden Heart of The Nature: Piper betle L. Journal of Pharmacognosy and Phytochemistry, 1 (6) : 147-167.

Pramono, Taufik Budhi., Syakuri, Hamdan. 2008. Infeksi Parasit Pada Permukaan Tubuh Ikan Nilem (Osteochillus hasselti) Yang Diperdagangkan Di PPI Purbalingga. Berkala Ilmiah Perikanan, 3 (2) : 79-82.

Prasetya, Novy., Subekti, Sri., Kismiyati. 2013. Prevalensi Ektoparasit Yang Menyerang Benih Ikan Koi (Cyprinus carpio) Di Bursa Ikan Hias Surabaya. Jurnal Ilmiah Perikanan dan Kelautan, 5 (1) : 113-116.

Purwanti, Retno., Susanti, R., Martuti, Nana Kariada Tri. 2012. Pengaruh Ekstrak Jahe Terhadap Penurunan Jumlah Ektoparasit Protozoa Pada Benih Kerapu Macan. Unnes Journal of life science, 1 (2) : 70-77.

Rahim, F. N., Tuiyo, R., \& Muharam, A. (2016). Pengaruh Perendaman dengan Larutan Daun Sirih Terhadap Sintasan Benih Ikan Nila yang Terinfeksi Trichodina sp. Nike: Jurnal Ilmiah Perikanan Dan Kelautan, 4(4), 127-131. 
Rekha, V. P. B., Kollipara, M., Gupta, B. R. S. S. S., Bharath, Y., \& Pulicherla, K. K. (2014). A Review on Piper betle L.: Nature's Promising Medicinal Reservoir. American Journal of Ethnomedicine, 1(5), 276-289.

Rustikawati, I., Rostika, R., Herlina, E. 2004. Intensitas dan Prevalensi Ektoparasit Pada Benih Ikan Mas (Cyprinus carpio L.) Yang Berasal Dari Kolam Tradisional Dan Longnyam Di Desa Sukamulya Kecamatan Singaparna Kabupaten Tasikmalaya. Jurnal Akuakultur Indonesia, 3 (3) : 33-39.

Setiadi, Riki. 2008. Efektifitas Perendaman 24 Jam Benih Lele Dumbo Clarias sp. Dalam Larutan Paci-Paci Leucas lafandulaefolia Terhadap Perkembangan Perkembangan Populasi Trichodina sp. Skripsi. Program Studi Teknologi Dan Manajemen Akuakultur. Fakultas Perikanan Dan Ilmu Kelautan. Institut Pertanian Bogor.

Wiyatno, Ferlyn Hendra., Subekti, Sri., Kusdarwati, Rahayu. 2012. Identifikasi Dan Prevalensi Ektoparasit Pada Ikan Kerapu Tikus (Cromileptes altivelis) Di Karamba Jaring Apung Unit Pengelola Budidaya Laut Situbondo. Jurnal Ilmiah Perikanan dan Kelautan, 4 (1) : 103-108. 